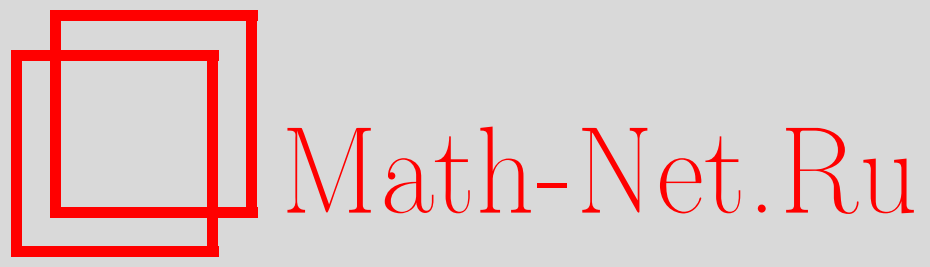

Л. Белопухов, Петр Леонидович Капица (к 125-летию со дня рождения), Квант, 2019, номер 1, 2-11

DOI: https://doi.org/10.4213/kvant20190101

Использование Общероссийского математического портала Math-Net.Ru подразумевает, что вы прочитали и согласны с пользовательским соглашением http: //www . mathnet.ru/rus/agreement

Параметры загрузки:

IP : 54.237 .59 .107

26 апреля 2023 г., 10:58:54

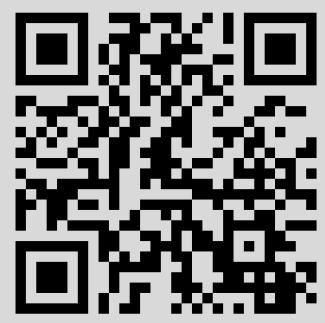




\section{Петр Леонидович Капица \\ (к 125-летию со дня рождения)}

\section{Л.БЕЛОПУХОВ}

O ДНАЖДЫ В 1921 ГОДУ ДВА МОЛОДЫХ человека, поклонники живописи Б.М.Кустодиева, зашли в мастерскую этого петроградского художника и попросили его нарисовать их парный портрет. А Кустодиев как раз в это время прославился портретами известных людей (особенно портретом Ф.И.Шаляпина). Они сказали, что пока их никто не знает, но вся известность у них впереди. Художнику они понравились своей уверенностью в будущей известности, и он согласился.

Через несколько десятков лет эти молодые люди действительно стали всемирно известными учеными, лауреатами Нобелевской премии: один по физике, другой по химии. Тот, который с трубкой, это 27летний Петр Леонидович Капица, другой - 25-летний Николай Николаевич Семенов.

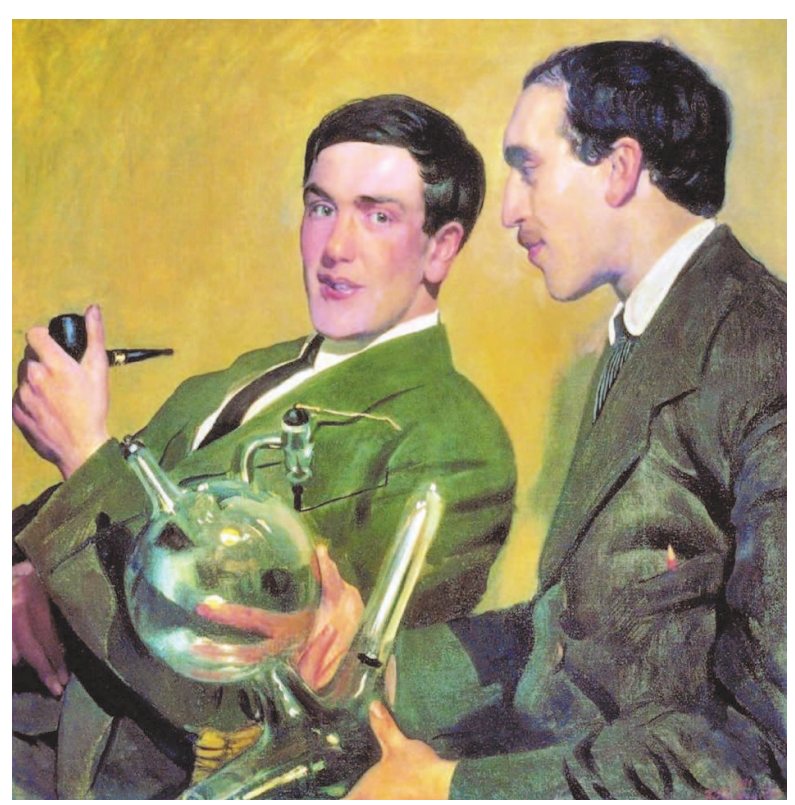

DOI: https://doi.org/10.4213/kvant20190101
Петр Леонидович Капица (1894-1984) великий физик и инженер. В физике он прежде всего - экспериментатор. Его работы по физике и технике сверхсильных магнитных полей, по физике и технике низких температур, по сверхтекучести жидкого гелия, по электронике больших мощностей и физике высокотемпературной плазмы - это классика современного физического эксперимента. Во многом эти эксперименты способствовали развитию квантовой физики в ее конкретных применениях.

Шедевром инженерных идей Капицы было усовершенствование адиабатического метода получения сверхнизких температур с предварительным сжатием газа турбиной, источником энергии которой была отнимаемая у газа теплота. Коэффициент полезного действия холодильной машины Капицы - турбодетандера был необычайно высоким (выше 80\%), что позволило заметно удешевить производство так необходимого ему жидкого гелия. Но оказалось не менее важным и применение турбодетандеров для получения жидкого азота и, особенно, жидкого кислорода.

Не меньшую известность, чем в физике, Капица заслужил своей общественной позицией, основанной на жизненной философии. Директор Института физических проблем с 1990 по 2017 год, ученик Капицы и Ландау, академик А.Ф.Андреев так пишет о нем: «На долю Капицы выпало много страданий и много побед. Как в научном, так и в человеческом плане. При всей глубокой индивидуальности Петра Леонидовича, а может быть именно вследствие этого, его судьба многократно воспроизводит картину времени». 
Даже кратко трудно рассказать о жизни и судьбе П.Л.Капицы. Его отец Леонид Петрович Капица произошел из польскомолдавского шляхетского рода КапицМислевских. Он закончил Николаевскую военно-инженерную академию и стал военно-морским инженером, строителем портовых сооружений, одним из создателей укреплений Кронштадского военно-морского порта, имел чин генерал-майора инженерного корпуса. Умер он в 1920 году. Мать Капицы Ольга Иеронимовна Стебницкая, дочь военного картографа, главного геодезиста Кавказа, окончила знаменитые женские Бестужевские курсы. Она стала специалистом по детской литературе и фольклору, преподавала в Ленинградском педагогическом институте имени А.И.Герцена. Умерла она в 1937 году.

Безмятежные детство и отрочество Капицы были украшены летними путешествиями по Европе с матерью или отцом. В 18 лет, закончив Кронштадское реальное училище, Капица поступает на электромеханический факультет Петербургского политехнического института, созданный и руководимый физиком А.Ф.Иоффе. Он вскоре привлек талантливого второкурсника к научной работе в физической лаборатории.

Интересно, что свои первые летние каникулы в 1913 году Капица проводит с братом Леонидом, студентом-географом, на русском Севере, на Соловках и на побережье Кольского полуострова, собирая этнографические материалы. Появляется первая журнальная работа - научнопопулярная статья «Рыбий жир». Но уже во вторые каникулы его интересует не этнография, а инженерные вопросы строительства кораблей. И он проводит эти каникулы в Шотландии, живет в семье предпринимателя-кораблестроителя и по примеру Петра Великого осваивает рабочие профессии корабела.

Из-за разыгравшейся мировой войны он смог вернуться в Россию только в 1915 году и немедленно зачислился добровольцем - шофером и механиком в санитарный фронтовой отряд. К учебному году он возвращается на учебу на третий курс института. В это время он знакомится с 18летней Надеждой Кирилловной Черносвитовой, дочерью крупного политика, члена ЦК партии кадетов, расстрелянного в 1918 году. Она становится его невестой. Девушка живет в Шанхае, в семье своего брата, сотрудника Русско-Азиатского банка, и учится в шанхайской русской гимназии. Летом 1916 года Капица едет в Шанхай и привозит невесту в Россию. В имении отца невесты состоялась свадьба.

В это же время публикуются две первые научные работы молодого студента, одна теоретическая, другая - экспериментальная. Экспериментальная особенно интересна. В ней Капица излагает созданный им метод изготовления очень тонких металлических нитей. Метод заключался в стрельбе вверх из устройства, похожего на мальчишескую рогатку, кусочком затвердевающего расплавленного металла, который по мере полета и превращался в застывшую тончайшую, но прочную нить.

Богато событиями для Капицы лето 1917 года - практика в радиотелеграфном отделении завода-концерна «Сименс и Гальске» и рождение сына Иеронима. Еще полтора года учебы и научной работы, и Капица - инженер-электрик, преподаватель Политехнического института и научный сотрудник Физико-технического института (в лаборатории А.Ф.Иоффе).

Наступает зима 1919-20 года. В течение месяца эпидемия гриппа («испанка») уносит отца, сына и жену с новорожденной дочерью. Спасение от удара судьбы только в научной работе и нежной опеке матери. Не оставляют и друзья. С самым близким другом, Николаем Николаевичем Семеновым, Капица рассчитывает взаимодействие атомов с сильно неоднородным магнитным полем и обсуждает идею экспериментальной установки для изучения этого взаимодействия. Но публикация этой работы не состоялась - в России еще не было своего физического журнала, а добраться до европейских научных журналов не представлялось возможным. Поставить реальный эксперимент было невозможно из-за отсутствия необходимого оборудования. В 1922 году аналогичную работу выполняют 
немецкие физики О.Штерн и В.Герлах и публикуют свои результаты, сыгравшие важную роль в становлении квантовой атомной физики. В 1943 году Штерн стал нобелевским лауреатом «за ...измерение магнитного момента протона», а раздел «опыты Штерна и Герлаха» включен во все современные учебные программы вузовских курсов физики.

Чтобы спасти Капицу от развивающейся депрессии, А.Ф.Иоффе включает его в состав комиссии Российской академии наук, направляемой, по предложению В.И.Ленина, в страны Западной Европы для восстановления научных связей, приобретения приборов и научной литературы. Вот как высоко ценило фундаментальную науку и понимало ее необходимость тогдашнее руководство страны, разрушенной революциями и гражданской войной. Перед отъездом Капицы и был написан тот самый парный портрет двух друзей.

При посещении Кембриджской лаборатории 27-летний инженер П.Л.Капица обращается к ее руководителю, знаменитому физику Э.Резерфорду, с просьбой взять

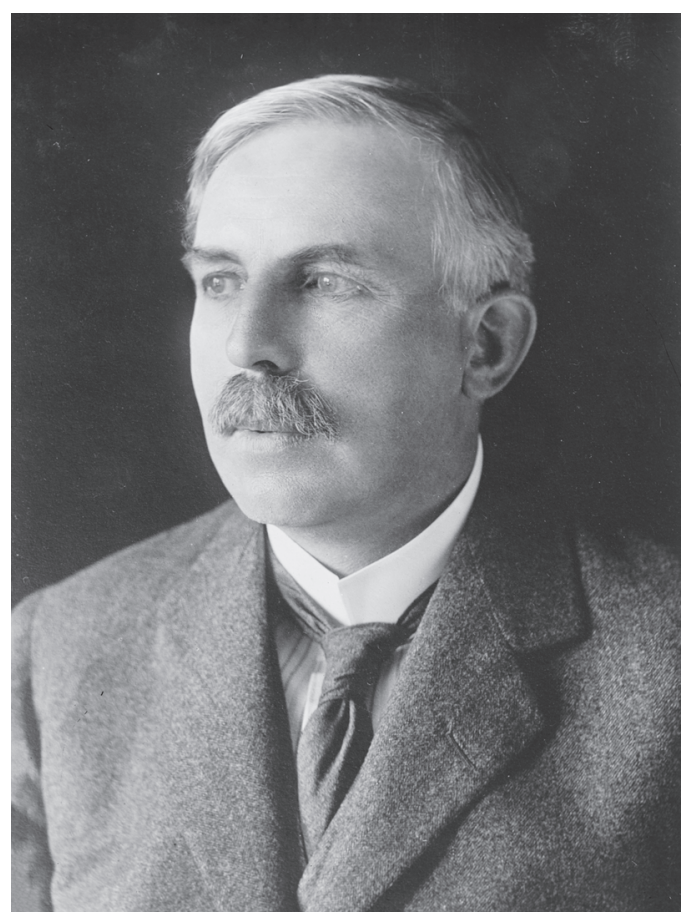

Эрнест Резерфорд его на стажировку. Тот, естественно, отказывает, мотивируя это отсутствием свободных вакансий и опасностью риска брать на работу к себе неизвестного человека, да еще и из Советской России. Тогда Капица задает Резерфорду вопрос: «А какой процент ошибки вы допускаете в своих экспериментах?» Резерфорд не понимает, к чему этот вопрос, но отвечает: «Ну, обычно, три-четыре процента». А Капица в ответ: «У вас 30 сотрудников, пусть будет 31, это и будет три процента. Можете рискнуть». Ошеломленный остроумием и находчивостью Капицы, Резерфорд берет его к себе на стажировку и никогда потом об этом не пожалеет.

Уже через два года Капица создает импульсный генератор для получения магнитных полей. Физическая суть этой работы проста - заряженный большим зарядом аккумулятор разряжается через маленький соленоид. Сила тока в соленоиде при этом достигает десятков тысяч ампер, а рождаемое им магнитное поле - десятков тесла, что в десять тысяч раз больше индукции магнитного поля Земли. Разряд был импульсным, длился сотые доли секунды, и соленоид не успевал нагреться до разрушающей температуры. Но за это время можно было успеть зафиксировать все, что происходит с заряженными частицами в магнитном поле. Любопытно, что это были альфа-частицы, т.е. ядра атомов гелия. А через несколько лет Капица начинает опыты именно с жидким гелием, опыты, которые его прославили.

Капица становится доктором Кембриджского университета, заместителем Э.Резерфорда. Создает в Кембридже физический семинар, получивший впоследствии название «клуб Капицы», где в неформальной обстановке обсуждаются проблемы не только физики. Между делом Капица становится чемпионом по шахматам графства Кембриджшир.

Капица быстро прославился среди ученых Кембриджа своей эксцентричностью. Именно он придумал Резерфорду прозвище «крокодил». Оно вскоре стало широко применяемым и, по-видимому, понравилось самому прообразу. Когда в 1933 году 
было закончено строительство Мондовской лаборатории для Капицы, то при ее торжественном открытии выяснилось, что солидный входной ключ представлял собой фигуру крокодила, открывающего замок, а в вестибюле лаборатории всех встречал барельеф, на котором был изображен крокодил. Резерфорд промолчал, а почти все присутствовавшие одобрили подобную вольность, особенно Нильс Бор.

Вот еще одна черта эксцентричности Капицы. Огромным удовольствием для него была бешеная езда на мощном автомобиле. Его нормой была скорость 60 миль в час (около $110 \mathrm{\kappa м} /$ ч), тогда как разрешенный максимум был 40 миль в час. Когда однажды перепуганный пассажир, священник и историк Симпсон, обратил внимание Капицы на показания спидометра, он ответил, что это специально переделанный для него прибор и что он показывает не английские мили, а русские километры. А перед опасным поворотом приговаривал: «Молитесь, Симпсон, молитесь богу!»

Искренняя дружба связывала П.Л.Капицу с Н.Н.Семеновым еще со студенческих времен. До преклонных лет они и в письмах, и в живом общении называли друг друга «Петька» и «Колька». После отъезда Капицы в Кембридж они не виделись несколько лет. В 1926 году Семенов командируется в Англию и Францию. В Кембридже он встречается с другом «Петькой» и знакомит его со своей женой. А в Париже жена Семенова знакомит Капицу со своей гимназической подругой Анной Алексеевной Крыловой, дочерью крупного ученого, математика и кораблестроителя А.Н.Крылова. Гражданская война разрушила его семью - погибли два сына (деникинские офицеры), а жена с дочерью эмигрировали во Францию.

В свои 23 года Анна успела много пережить и тосковала в Париже по своей родине и окружавшей ее с детства обстановке русской научной культуры. У нее оказалось много общего с молодым русским физиком. В 1927 году Петр Капица и Анна Крылова соединили свои судьбы. Они прожили вмести 57 лет. Анна Алексе-

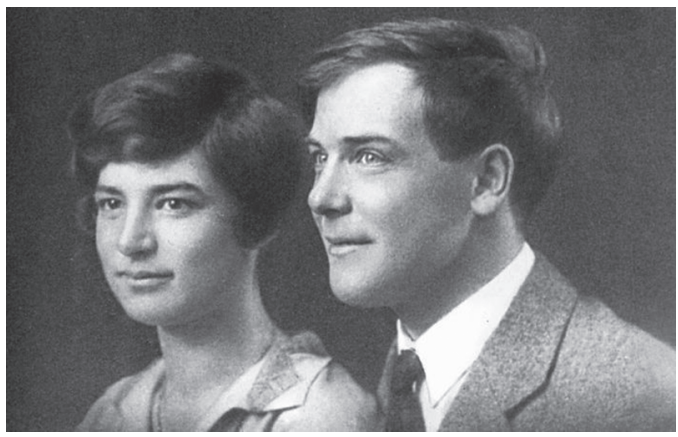

Анна Алексеевна и Петр Леонидович (Париж, 1927 г.)

евна не только сумела создать Капице прочно обеспеченный семейный «тыл», но и была главной его моральной опорой во всех невзгодах, во всех несправедливостях жизни.

В Кембридже рождается их сын Сергей (1928-2012), тоже физик, но получивший бо́льшую известность как популяризатор науки, создатель и в течение почти 40 лет бессменный ведущий знаменитой научнопопулярной телепередачи «Очевидное невероятное». Сегодня в Москве наряду с улицей Академика Капицы есть и улица Сергея Капицы.

Через три года рождается второй сын Андрей (1931-2011), географ, исследователь последнего в ХХ веке крупного географического открытия - существования огромного подледного озера в Антарктиде, инициатор создания и первый директор Тихоокеанского института географии Дальневосточного научного центра АН СССР.

Научные интересы Капицы все больше сосредотачиваются на получении жидкого гелия и изучении его свойств. Его инженерный талант и умение привлекают внимание многих промышленных фирм - его приглашают для консультаций, в том числе и в военно-промышленные организации. Консультации щедро оплачиваются. Капица становится материально обеспеченным человеком. С одной из таких консультаций связан знаменитый, нет, не анекдот, а рассказ о реальном событии. При оговоренной оплате за консультацию в тысячу фунтов стерлингов Капица осматривает непонятно по какой причине неработающий агрегат. Он знакомится с черте- 
жами, внимательно исследует все узлы агрегата и вдруг наносит сильный удар в один из узлов машины. Машина заработала и продолжала исправно работать. Заказчики заявили: «За что же платить 1000 фунтов?» Капица ответил: «За удар один фунт, а 999 фунтов за то, что нужно было знать, куда ударить».

И вдруг все изменилось. В один из ежегодных приездов на летний отдых и чтение лекций в Москве, Ленинграде и Харькове в 1934 году его заграничная виза аннулируется и он лишается международного паспорта. Формальной причиной этого стали его консультации «буржуазным» фирмам, в том числе и военно-промышленным. Жена уезжает к оставшимся в Кембридже с бабушкой сыновьям. А Капица занимает непримиримую позицию и заявляет, что если ему не обеспечат то же самое научное оборудование, которое он организовал в Кембридже, то он оставляет физику и идет работать рядовым инженером в биологический институт к великому И.П.Павлову.

Резерфорд взбешен этим поступком советского правительства и инициирует осудительную кампанию в прессе. Правительство СССР струсило и издает постановление о создании для Капицы специального института и закупке в Англии у Резерфорда оборудования кембриджской лаборатории. Резерфорд идет Капице навстречу, согласившись на продажу оборудования, так сказать, по себестоимости, и кроме того направляет в Москву двух инженеров для его наладки.

В Москве на выбранном Капицей месте - на Воробьевых горах, на высоком берегу Москвы-реки - строится новый академический Институт физических проблем с необходимыми службами и коттеджем для Капицы и его семьи. Капица становится директором своего института на необычных условиях полной самостоятельности в вопросах управления институтом. В нем вначале числилось всего лишь 15 научных сотрудников, зато больше 100 инженеров и техников и только 3 сотрудника для управления. В институте нет отдела кадров, Капица сам знакомится с каждым новым сотрудником - от ведущих ученых до дворника. Например, увольняет троих дворников-бездельников и заменяет их одним, но за тройную оплату, благо так называемая финансовая дисциплина его не касается. Главного бухгалтера у него нет, он сам ведает распределением средств, есть только счетовод-кассир. На должность своего помощника он находит Ольгу Александровну Стецкую, сотрудницу Н.К.Крупской, вхожую во все властные кабинеты и к тому же имевшую мужем видного партийного деятеля. Долгие годы она освобождала Капицу от всех хлопотных дел, связанных с различными «инстанциями» .

А.Ф.Иоффе делает Капице «царский» подарок, отдав одного из двух братьевстеклодувов Петушковых, необычайных умельцев по работе со стеклом (а в экспериментах с жидким гелием это было, ох, как необходимо). Главным экспериментатором у Капицы становится Александр Иосифович Шальников, будущий академик (1979), трижды лауреат Государственных (Сталинских) премий СССР, автор многих экспериментальных открытий, в которых проявлялись квантовая сущность явлений сверхтекучести, сверхпроводимости, фононного газа в кристаллах, особенности полупроводников и многое другое. А Петр Леонидович Капица, руководитель и постановщик этих работ, стал не только классиком естествознания, но и ученым, находящимся на переднем крае современной физики. Для теоретического осмысливания своих экспериментальных достижений Капица приглашает и делает заведующим теоретическим отделом института молодого, но уже ставшего европейски известным физика-теоретика Льва Давыдовича Ландау (1908-1968), будущего лауреата Нобелевской премии «за пионерские теории конденсированных сред и особенно жидкого гелия» .

Важную роль сыграл организованный Капицей еженедельный семинар по физике, получивший неофициальное имя «капишник». На семинаре обсуждались не только работы института, но и все важнейшие новые научные работы по физике как 


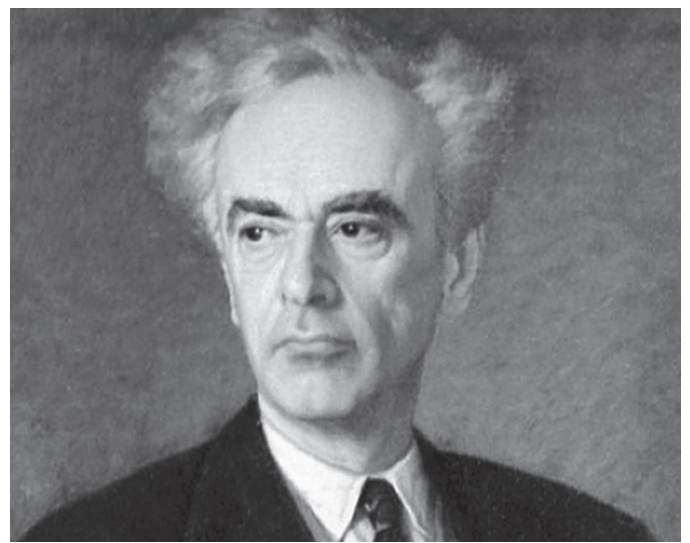

Лев Давыдович Ландау

в нашей стране, так и за рубежом. Семинар всегда вел сам Капица и вел его необычайно организованно - основной доклад и выступления были строго ограничены во времени и прерывались «на полуслове» в случае нарушения регламента. Председательствующий своими вопросами обострял самую сущность обсуждаемой проблемы. И в то же время «климат» этих семинаров был неизменно благоприятный, уважительный. И никогда на семинарах не было псевдофилософских обсуждений проблем физики или амбициозных выступлений с нападками на коллег. Выяснялась только подтверждаемая экспериментом научная истина.

В 30-е годы Капица прежде всего заканчивает свои работы по турбодетандеру, которые предопределили развитие во всем мире современных установок разделения воздуха на азот, кислород, аргон и гелий. Жидкий кислород стал одним из важнейших стратегических материалов в военные годы. Ведь сталь для танковой брони с добавками тугоплавких металлов (вольфрама и др.) можно было получить только с использованием в мартеновских печах кислородного дутья, позволяющего достичь более высокой температуры плавления такой стали. И он прилагает большие усилия для внедрения своего детища в промышленность - нашлось много противников из среды научных чиновников, желающих внедрять свои собственные изобретения и бесчестно искажавших эффективность турбодетандера. Но факт успеш- ного применения турбодетандеров во всем мире повлиял на руководство страны, и в 1941 году Капица в числе первых ученых становится лауреатом Сталинской премии первой степени за свой турбодетандер, а в 1943 году назначается начальником «Главкислорода» - Главного управления кислородной промышленности при СНК СССР, на должность выше наркомовской. В 1945 году он становится Героем Социалистического Труда. Но эта инженерная и организационная деятельность была для Капицы в значительной степени вынужденной в связи с событиями тех лет. Капица понимал, что в грядущей войне решающую роль будут играть танковые сражения.

Основные научные интересы Капицы были сосредоточены в другой области. Имея с помощью своего турбодетандера необходимое количество жидкого гелия, он развернул работы по изучению его свойств. В 1937 году было сделано фундаментальное открытие. В чрезвычайно изящных экспериментах, изучая протекание жидкого гелия через узкие щели, Капица установил, что при температуре ниже 2,19 К исчезает его вязкость. Происходит фазовый переход (второго рода) гелия-I в гелий-II, обладающий рядом необычных свойств и прежде всего отсутствием вязкости, т.е. сверхтекучестью. Скачком меняются теплоемкость и ряд других тепловых характеристик гелия. Эти эксперименты были не просто изящными, они были очень трудными. Достаточно отметить, что на первых порах только два человека могли перелить сверхтекучий жидкий гелий из дьюаровского сосуда в пробирку - сам Капица и его главный экспериментатор Шальников, причем у Шальникова это получалось даже лучше.

Капице было ясно, что объяснение таких странных свойств гелия лежит за пределами классических представлений о веществе. И действительно, первая теория сверхтекучести была создана Л.Д.Ландау в 1941 году как квантово-механическая теория. На основе экспериментов Капицы и теории Ландау родилась физика квантовых жидкостей как макроскопическое проявление квантового поведения частиц. 
В 1945 году грянула «атомная эра». В августе этого года США отомстили японскому народу за нападение японской авиации (без объявления войны) на американскую военно-морскую базу на Гавайях в декабре 1941 года. Но месть была слишком неадекватной. Тогда погибло 2403 человека и было ранено 1178. А в Хиросиме и Нагасаки почти мгновенно погибли больше 100000 человек, и еще 200000 в течение нескольких лет умирали вследствие лучевого поражения. Кроме идеи отмщения, эта акция носила очевидный характер устрашения СССР. Советским физикам стало ясно, что в вопросе использования ядерной энергии они сильно отстали от зарубежных ученых.

В 1946 году был создан специальный Государственный комитет - без названия, а просто №1 - под начальствованием Л.П.Берии. Первоначально в него входили только два физика - Капица и Курчатов. Но, в отличие от Курчатова, Капице не был доверен высший государственный секрет получение нашей разведкой подробных (и, главное, достоверных) сведений не только принципиальных схем ядерных бомб, но и чертежей ее основных узлов. Ничего не зная об этом, Капица, движимый патриотическими чувствами, разрабатывает рассчитанный на два года проект развертывания всех работ, необходимых, по его мнению, для создания ядерного оружия. Капица удивляется, почему его проект даже не обсуждается. Он не подозревает того, что Сталин и Берия твердо решили довериться данным разведки и скопировать американскую бомбу. А Курчатову ясно, что это сможет значительно ускорить создание советской бомбы, и, самое главное, ему понятно, что после атомных бомбардировок никакого секрета уже нет. Конструкции отдельных узлов бомбы уже не имеют принципиального значения. Главная трудность состоит в наработке необходимого количества ядерного «топлива» - изотопа урана-235 и плутония.

В данных разведки Курчатов усмотрел сведения о гигантских заводах, сооруженных для этих целей в США, и понял, что это и есть основное поле деятельности
Государственного комитета. Но Капица о масштабах этих работ не догадывается, он думает о создании физики бомбы. Уязвленный тем, что руководитель комитета Берия в физике ничего не понимает, он пишет Сталину письмо о его безграмотности, сравнивая Берию с дирижером, который пытается руководить оркестром, даже не зная нотной грамоты. Сталин показывает письмо Берии, и тот, взбешенный, обещает стереть великого физика «в лагерную пыль». Сталин же говорит Берии, что снимет Капицу в наказание со всех постов, но трогать его не надо.

И на другой день Капица - уже не член Государственного комитета, не начальник «Главкислорода», не директор Института физических проблем. Он - просто академик и профессор МГУ. У него отбирают оборудованный им по своему вкусу коттедж во дворе института, поскольку для прохода во двор нужен спецпропуск, который у него попросту забирают. Но Сталин оставляет ему академическую дачу в поселке Николина гора неподалеку от Звенигорода. Президент Академии наук СССР С.И.Вавилов делает все, что может. Он обеспечивает дачный сарай, который вскоре прозвали «избой физических проблем», несколькими станками, материалами, рабочими и инженером.

$\mathrm{B}$ «избе» работа с жидким гелием, конечно, была невозможна. И Капица переключается на совсем другие дела - создание мощных сверхвысокочастотных генераторов импульсного и непрерывного действия и изучение свойств плазмы, получающейся при действии таких генераторов на газовый разряд, в частности на изучение природы шаровой молнии, которую он смог получить в лабораторных условиях. Генераторы Капицы легли в основу устройств, оказавшихся совершенно необходимыми в современных работах по овладению термоядерной энергией в токамаках.

Для осуществления этих работ оказалось крайне важным то, что Капица был удивительно «рукастым» физиком-экспериментатором. Недаром еще Резерфорд назвал его мастером «золотые руки». Капица умел делать все - паять схемы, 
работать на станках, выдувать стеклянные сосуды, сооружать сложные установки. Он обучил рукоделию своих сыновей, и они на сухопутной Николиной горе и малюсенькой там Москве-реке сделали прекрасную морскую яхту и совершали на ней потом интересные путешествия.

К Капице на Николину гору приезжают друзья и коллеги, работает, хоть и не регулярно, ставший нелегальным «капишник». Блестяще продолжается его педагогическая деятельность на физико-техническом факультете МГУ.

Но в 1950 году, придравшись к пустяшному поводу, его отстраняют от руководства кафедрой на физтехе и чтения там лекций. А директорствовать в Институте физических проблем соглашается один из сподвижников И.В.Курчатова, будущий президент Академии наук СССР А.П.Александров, которому Капица так и не простил его согласия на этот пост. Впрочем, Александров сохранил все направления исследований, которыми руководил Капица, и в особенности теоретический отдел, возглавляемый Л.Д.Ландау. Так проходит восемь лет.

Как по мановению волшебной палочки, все изменилось после смерти Сталина и падения Берии. Капица вновь становится директором Института физических проблем и главным редактором самого авторитетного научного журнала - «Журнала экспериментальной и теоретической физики». Наряду с И.Е.Таммом, только более резко, он в Академии наук борется за восстановление в СССР биологической науки, разрушенной псевдонаучной деятельностью Т.Д.Лысенко и его последователей.

Возобновляется полноценная работа «капишника», который становится не только центром физической науки, но и культурным центром Москвы, когда на его заседаниях научная тема заменяется выступлениями артистов, писателей, поэтов. И на такие «капишники» стремилась попасть «вся Москва». В этих случаях приходилось организовывать радиотрансляцию из зала заседаний по всем помещениям здания - они были заполнены гостями.
В 1974 году в дни своего восьмидесятилетия Капица становится дважды Героем Социалистического Труда. А в 1978 году его, наконец, настигла давно заслуженная Нобелевская премия «за базовые исследования и открытия в области низких температур».

Характерно, что, необычайно щедрый в жизни, Капица не отдал ни копейки из полученной премии государству. Капица любил Россию, он никогда не соглашался покинуть ее, несмотря на неоднократные предложения многих научных мировых центров. Но он активно не любил российские правительства: ни сталинское, ни хрущевское, ни брежневское. Он никак не мог примириться, например, с тем, что для получения каких-либо пустяшных материалов или деталей нужно обивать пороги, а, главное, терять месяцы, тогда как «в Англии у меня на это ушло бы два дня», как он пишет в одном из писем правительственным деятелям. Так, в эпоху становления своего института Капица обратился в один из наркоматов с просьбой об инструментах и измерительных приборах. Ему предложили оформить заявку «на будущий год»...

Капица не доверял телефону, во-первых, из-за возможного прослушивания органами, а во-вторых, из-за трудности обоснования своей позиции вследствие вынужденной краткости тогдашних телефонных разговоров (особенно, по кремлевской «вертушке»). Он предпочитал письменные объяснения. Руководителям советского государства он написал свыше

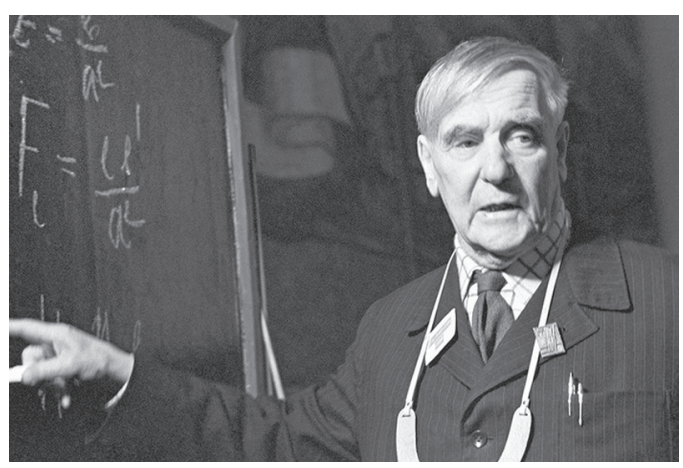

П.Л.Капица у доски 


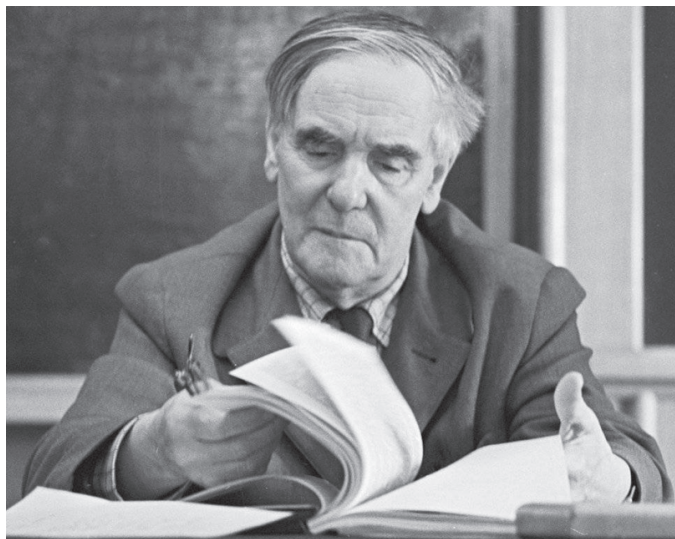

П.Л.Капица за рабочим столом

300 (!) писем, из них 50 - И.В.Сталину. Иногда были и ответы. В архиве Капицы хранится такое письмо: «тов. Капица! Все Ваши письма получил. В письмах много поучительного - думаю как-нибудь встретиться с Вами и побеседовать об этом. Что касается книги Л.Гумилевского «Русские инженеры», то она очень интересна и будет издана в скором времени. И.Сталин. 6 апреля 46 г.». Были и ответы действием.

П.Л.Капица неоднократно вступался в 30-е годы за арестованных или подвергавшихся травле ученых. По крайней мере в трех случаях письма Капицы оказались для них спасением. В 1936 году внезапно прекратилась развернувшаяся в прессе кампания травли выдающегося математика академика Н.Н.Лузина. Арестованного физика-теоретика В.А.Фока освободили через несколько дней. Труднее всего оказалась борьба Капицы за освобождение Л.Д.Ландау. Он был арестован за участие в группе, распространявшей листовки с антисоветским содержанием. И хотя его участие в этой группе было лишь формальным, на уровне разговоров, он был обвинен в шпионаже в пользу Германии. Требуя от него подтверждения такого чудовищного обвинения, Ландау был подвергнут особо изощренной пытке голодом. Из соседнего санатория приносили столовую ложку необычайно вкусной еды, и это было все за целый день. Ему грозила смерть, но он упорно не давал никаких ложных показаний. В защиту Ландау Ка- пица написал несколько десятков писем, ручался «за его примерное поведение» и, наконец, поехал в Кремль и заявил, что, если Ландау не освободят, он прекращает заниматься наукой. На другой день Ландау был освобожден.

В 1970-е годы, когда разгорелась травля академика А.Д.Сахарова, Капица был единственным, кто открыто восстал против исключения Сахарова из Академии наук. На заседании Президиума Академии с участием партийного начальства он нашел нужные слова: «Аналогичный позорный инцидент уже был. В 1933 году фашисты исключили из берлинской академии Альберта Эйнштейна». Наверное, после этого выступления многим академикам стало в глубине души неловко за свое непротивление начальственному нажиму. На даче Капицы неоднократно бывали и сам Сахаров, и Солженицын, и многие другие представители культуры, деятельность которых не одобрялась властью.

Вообще, гуманитарные интересы Капицы были очень широкими. Он хорошо знал европейские памятники культуры. Вернувшись в Россию, он только после войны смог найти время для экскурсии по «Золотому кольцу», как впоследствии стали называть такие поездки. Его сопровождали искусствоведы, и он прошел с ними основательный курс истории древнерусской культуры. В те годы все памятники старины Владимира, Суздаля и других городов, а особенно великая церковь Покрова на Нерли, были в запустении. Потрясенный красотой древних храмов, Капица обращается в правительство не просто с письмом. Свое обращение он назвал «Меморандум о памятниках старины Владимирской области». Это было подробное описание запустения, в котором находились памятники культуры, и в то же время детальная программа того, что необходимо сделать для восстановления и сохранения этих памятников.

Весть о присуждении Нобелевской премии застала Капицу в академическом санатории в Узком, на окраине Москвы, где он отдыхал вместе с женой. Налетевшим через час корреспондентам на вопрос о том, 
какие свои достижения он считает наиболее значительными, Капица сказал, что для ученого всегда наиболее важна та работа, которой он занимается в данный момент. «У меня такая работа относится к термоядерному синтезу», - добавил он. И в своей Нобелевской лекции он, допустив вольность, продолжил эту тему. Вопреки уставу Нобелевского фонда, лекция не была посвящена работам, отмеченным премией. Она называлась «Плазма и термоядерная реакция». Капица сказал, что сверхнизкими температурами он занимался очень давно, в дни научной молодости. А сейчас, наоборот, его волнуют сверхвысокие температуры, которые необходимы для инициирования и поддерживания термоядерной реакции изотопов водорода. Крайности сомкнулись. ( Les extremes se touchent», - привел он знаменитое французское выражение.) Тем более, что жидкий гелий, за работы с которым присуждена награда, нужен и в этом деле для охлаждения обмоток сверхсильных магнитов, удерживающих раскаленную плазму. И он закончил лекцию словами: «Хорошо известно, что в данное время управляемая термоядерная реакция представляет большой практический интерес, так как этот процесс мог бы наиболее эффективно решить проблему глобального энергетического кризиса, связанного с истощением запасов ископаемого сырья, используемого теперь как источник энергии». Сегодня, через 40 с лишним лет, эти пророческие слова претворяются в жизнь мировым научным сообществом и правительствами ведущих стран мира, в том числе и России.

Очень важной была педагогическая деятельность Капицы. В 1945 году он был одним из главных инициаторов создания для подготовки физиков вуза нового типа, где обучение велось бы не только в стенах учебного заведения, а большей частью - в лабораториях научно-исследовательских институтов, где преподавателями должны быть ведущие ученые. И такой вуз был создан. Вначале это был секретный (атомно-ракетный) физико-технический факультет МГУ, а в 1951 году он стал Физикотехническим институтом, знаменитым
Физтехом. Капица возглавил там кафедру общей и экспериментальной физики. В первые годы лекции по этому предмету читали по очереди сам Капица и Ландау. Теоретик Ландау излагал теоретические основы очередной темы, а на следующей лекции Капица рассказывал об экспериментальных и исторических основах этого раздела физики. Это было потрясающе интересно. Студенты после предыдущего занятия стремглав неслись по коридорам Физтеха, чтобы успеть занять места поближе к замечательным лекторам.

В книге «П.Л.Капица. Эксперимент. Теория. Практика» (М.: Наука, 1974) собраны статьи и выступления Капицы по самым разным темам. Книга позволяет понять необычайный дар Капицы рассказывать о самых сложных проблемах науки доходчиво и интересно. Его сын, С.П.Капица, получил от отца часть этого дара и на Физтехе принял эстафету преподавания физики, став профессором кафедры общей физики и ее заведующим.

Знаменитый английский физик Поль Дирак был большим другом Капицы. Он неоднократно приезжал в Советский Союз увидеться с ним и с другим своим другом, И.Е.Таммом. В свой последний приезд в 1973 году Дирак часто бывал у Капицы на даче (И.Е.Тамма уже не стало). И когда Капица рассказал очередную историю из своей жизни, а рассказчик он был замечательный, Дирак не удержался от эмоционального: «Капица! Какая замечательная жизнь, я завидую Вам».

Действительно, жизнь Капицы - яркий пример беззаветного служения науке и бесстрашия перед лицом невежества и властности. Даже в самые мрачные времена советского изоляционизма Капица всегда отстаивал принципы интернационализма в науке. «Я твердо верю в интернациональность науки и верю в то, что настоящая наука должна быть вне всяких политических страстей и борьбы, как бы ее туда ни стремились вовлечь» (из письма Молотову от 7 мая 1935 г.).

Скончался Петр Леонидович Капица от инфаркта 8 апреля 1984 года, немного не дожив до своего девяностолетия. 